\title{
Adoption of Conservation Practices: Its Impact on Input Use and Performance in the Northern Region of Ghana
}

\author{
Mavis Boimah $^{1}$, Akwasi Mensah-Bonsu ${ }^{1}$, Yaw Osei-Asare ${ }^{1} \&$ Daniel B. Sarpong ${ }^{1}$ \\ ${ }^{1}$ Department of Agricultural Economics and Agribusiness, School of Agriculture, College of Basic and Applied \\ Sciences, University of Ghana, Legon, Ghana \\ Correspondence: Mavis Boimah, Department of Agricultural Economics and Agribusiness, School of Agriculture, \\ College of Basic and Applied Sciences, University of Ghana, P.O.Box AF 1492, Adenta-Accra, Ghana. E-mail: \\ nusinyoo@gmail.com
}

Received: June 25, 2018

doi:10.5539/jsd.v11n5p149
Accepted: August 21, $2018 \quad$ Online Published: September 28, 2018

URL: https://doi.org/10.5539/jsd.v11n5p149

\begin{abstract}
Conservation Agriculture (CA) is promoted worldwide on the basis of its contribution to economic, social, and environmental sustainability of agricultural production. In Ghana, despite the increasing interest in the promotion of CA and its practices, its rate of adoption is still low, mainly due to the conflicting evidences regarding its effectiveness. This paper contributes to the numerous debates by examining the impact of CA practices on hired labour, rates of inorganic fertilizers applied by adopters, maize yield, and profit of adopters. Using a cross-sectional data, a multinomial endogenous switching regression (MESR) model was employed to compute the Average Treatment Effect (ATE) and Average Treatment Effect on Treated (ATET) for yield, hired labour, inorganic fertilizer rate, and profit of adopters of CA practices. The study reveals that CA practices impact positively on hired labour employed on the farm, but have a negative impact on profits of adopters. No impact whatsoever of adoption of CA practices is observed on maize yield and also inorganic fertilizer application rates. Technical assistance, and training of farmers on strategies that minimize costs of production must be intensified to raise profits of adopters.
\end{abstract}

Keywords: average treatment effect, conservation agriculture, conventional agriculture, Ghana, Maize, multinomial endogenous switching regression model

\section{Introduction}

With the failure of the green revolution to meet the goals of sustainable production (Basu and Scholten, 2012), alternate technologies and practices were suggested and still emerging from rigorous research as the way forward to attaining sustainability in agriculture. One of these evolutions is "Conservation Agriculture" (CA) (Vanlauwe et al., 2014). The term "CA" emerged in the 1990s when efforts were made to group a number of crop management practices under a common name (e.g. zero/no-tillage, minimum tillage, etc.) (Hobbs, Sayre, and Gupta, 2008). The rationale for this grouping was that conservation agriculture should be viewed as an integrated management system based on three principles that are crucial to sustaining agricultural production (Hobbs, Sayre, and Gupta, 2008; Sommer et al., 2014; Vanlauwe et al., 2014). These principles consist of: (1) minimum physical soil disturbance by tillage practices (minimum and zero tillage practices); (2) permanent soil cover with plant materials (crop residues which also serve as mulch); (3) crop diversification in space and time (e.g. crop rotation, use of cover crops, and intercropping). Vanlauwe et al. (2014) propose a fourth principle: the proper management of soil fertility and the balancing of nutrient flows, including the integration of organic and inorganic fertilizers ${ }^{\text {Notel }}$. The application of conservation agriculture is however wide, functioning differently in different geographical locations including soil and crop types, as well as farming systems (Wall, 2007). Local adaptations can however present $\mathrm{CA}$ as differing from one geographical location to another, but of most importance is the conformity to the principles of CA (Erenstein, 2003).

In general, $\mathrm{CA}$ is defined as a management system that excludes the degradative components existing in conventional management systems by; removing practices that destroy the soil structure and which break down soil organic matter, the insufficient return of organic matter to the soil and lack of protection of the surface soil, and monoculture ( Wall et al., 2013). The benefits of CA has been empirically validated by various researchers including Thierfelder and Wall (2010) in Zambia, Efthimiadou et al. (2010) in Sourthern Greece, Silici et al. 
(2011) in Lesotho, South Africa, and Abdulai and Huffman (2014) in the Northern Region of Ghana. In view of these benefits, its widespread adoption is thought of as one that can; minimize cost of machinery, reduce carbon emissions, improve the quality of soils thus reducing erosion and other forms of negative externalities for society, increase crop-water availability, reduce the overall cost of production and improve upon productivity and food security (Stonehouse, 1997; Gowing and Palmer, 2008; Kassam et al., 2009). Conservation Agriculture is also seen as both an adaptive and mitigative measure to climate change (Thierfelder and Wall, 2010) and identified as one of the means through which sustainability in agriculture can be achieved (Webster, 1997; Gowing and Palmer, 2008; Sommer et al., 2014; Vanlauwe et al., 2014).

Despite the numerous benefits attributed to CA, its adoption has received little attention. Adoption of CA according to Giller, Witter, Corbeels, \& Tittonell (2009) and Brouder and Gomez-Macpherson (2014) is concentrated in five countries constituting $87 \%$ of the world's adoption. The United States of America leads with 26.5million ha, followed by Brazil (25.5million ha) and Argentina (25.5million ha), Australia (17.0million ha) and Canada (13.5million ha). Full adoption of $\mathrm{CA}^{\text {Note } 2}$ outside South America according to Bolliger et al. (2006) is rare. It is theorized by researchers and promoters as Pedzisa, Rugube, Winter-Nelson, Baylis, \& Mazvimavi (2015) point out but practically, partial adoption is observed because CA adoption comes in phases and takes a long time for the incorporation of its three principles. Low rates of adoption are documented in Africa (Giller et al., 2009; Arslan, McCarthy, Lipper, Asfaw, and Cattaneo 2014) especially sub-Saharan Africa (SSA) where zero uptake of CA is observed in most countries (Gowing and Palmer, 2008).

Land preparation in the early 1980's for crop production in Ghana was mainly through the slash and burn method. Because there was low pressure on land, farmers could leave their farmlands after the soil has lost its fertility mainly from the practice of burning for some years to farm another fertile land while the abandoned land regains its fertility. This practice was considered as sustainable because of the practice of shifting cultivation (Boahen et al., 2007). However, as population growth, development and industrialization of the nation began to compete with agriculture over limited land, the practice of shifting cultivation gradually diminished (Boahen et al., 2007; Akowuah, 2010). Slash and burn method of land preparation was now regarded as unsustainable for agricultural production, due to its resultant effect on soil nutrient depletion, coupled with successive declines in yield (Boahen et al., 2007).

The issue of declining agricultural productivity provoked the government to search for new technologies and practices that will help in improving upon the fertility of soils and hence on crop productivity (Boahen et al., 2007). Conservation practices: minimum tillage, the use of cover crops, and rotation of cereals and grains with legumes were among the practices suggested. Promotion of these practices among farmers started in Ghana in 1995 (Boahen et al., 2007) and is still on-going (Sarpong and Anyidoho, 2012; Etwire et al. 2013). The Council for Scientific and Industrial Research-Savanna Agricultural Research Institute (CSIR-SARI), ADVANCE Ghana, the International Fertilizer Development Cooperation (IFDC) are some of the organizations encouraging the use of conservation practices among crop farmers (Etwire et al., 2013; Martey et al., 2014; Dalton, Yahaya, and Naab, 2014).

Despite the increasing interest in the promotion of CA and its practices, its rate of adoption is still low (Boahen et al., 2007; Akowuah, 2010; Dalton et al., 2014). Numerous debates are still on-going regarding its effectiveness stemming from the conflicting evidences worldwide (Giller et al., 2009; Corbeels et al., 2014; Pannell, Llewellyn, and Corbeels, 2014). In Ghana, the impact of bunding (a water and soil conservation) technology on rice yield and net returns is studied by Abdulai and Huffman (2014). However, no study is identified in literature that examined the impact of minimum tillage, maize-legume rotations, and integrated organic-inorganic fertilizer application practices in maize production in Ghana. Meanwhile Maize is the most important grain crop and the most produced in the 10 regions of Ghana, accounting for 55\% of the nation's total grain production (Angelucci, 2013). In addition, it is considered as a very important crop for food security because $40 \%$ of harvest is consumed by the household (Akowuah, 2010). According to Birner \& Resnick (2010) gaps in knowledge must be closed so that nations, especially in Africa would be able to implement policies that favour development. A study to assess the impact of conservation practices on the production of maize is thus very relevant for policy formulation and implementation towards agricultural development and food security in Ghana. Against this backdrop, this paper analyses the impact of conservation practices adopted for maize production in the Northern Region of Ghana on yield, inorganic fertilizer application rate, on hired labour, and on maize profits.

\section{Materials and Methods}

\subsection{Data and Sampling}

The study employed primary data collected at a cross-section from three districts in the Northern Region of 
Ghana. A multi-stage sampling procedure was employed in the data collection process. The first stage involved a purposive selection of three districts; Kumbungu, West Mamprusi, and Yendi, because programmes and projects on conservation agriculture have taken place, while other programmes are still on going in these districts. In the second stage of the sampling procedure, five farming communities from each of the three districts were randomly selected. The third and final stage involved a random selection of maize farmers in the selected communities. In all 411 farmers were interviewed following the sample size estimation procedure by Bartlett, Kotrlik, and Higgins (2001) based on the 2010 population and housing census data.

\subsection{Farmers' Choice of Conservation Practices}

Adoption of the three CA practices - minimum tillage, maize-legume rotation, and integrated organic-inorganic fertilizer practices will yield seven possible outcomes (Table 1), with the base category being non-adoption of all three practices.

Table 1. Conservation practices used by maize farmers

\begin{tabular}{llll}
\hline Practice choice & Minimum tillage & Maize-legume rotation & $\begin{array}{l}\text { Organic-inorganic } \\
\text { fertilizer integration }\end{array}$ \\
& $\mathrm{M}_{1}$ & $\mathrm{R}_{1}$ & $\mathrm{~F}_{1}$ \\
\hline $\mathrm{M}_{0} \mathrm{R}_{0} \mathrm{~F}_{0}$ & & & \\
$\mathrm{M}_{1} \mathrm{R}_{0} \mathrm{~F}_{0}$ & $\sqrt{ }$ & $\sqrt{ }$ \\
$\mathrm{M}_{0} \mathrm{R}_{1} \mathrm{~F}_{0}$ & & & $\sqrt{ }$ \\
$\mathrm{M}_{0} \mathrm{R}_{0} \mathrm{~F}_{1}$ & $\sqrt{ }$ & $\sqrt{ }$ \\
$\mathrm{M}_{1} \mathrm{R}_{1} \mathrm{~F}_{0}$ & $\sqrt{ }$ & & $\sqrt{ }$ \\
$\mathrm{M}_{1} \mathrm{R}_{0} \mathrm{~F}_{1}$ & $\sqrt{ }$ & $\sqrt{ }$ & $\sqrt{ }$ \\
$\mathrm{M}_{0} \mathrm{R}_{1} \mathrm{~F}_{1}$ & & $\sqrt{ }$ & \\
$\mathrm{M}_{1} \mathrm{R}_{1} \mathrm{~F}_{1}$ & $\sqrt{ }$ & & \\
\hline
\end{tabular}

Note: adoption of conservation practices is denoted by $\mathrm{M}_{1}$ (minimum tillage), $\mathrm{R}_{1}$ (maize-legume rotation, and $F_{1}$ (organic-inorganic fertilizer). Non-adoption of the three conservation practices is denoted by $\mathrm{M}_{0} \mathrm{R}_{0} \mathrm{~F}_{0}$.

\subsection{Econometric Framework of the MESR Model}

Because farmers make their own choices endogenously, their decisions are likely to be influenced by unobservable characteristics (e.g. managerial skills). Self-selection by farmers to adopt a conservation practice or set of practices requires a selection correction estimation method such as the Multinomial Endogenous Switching Regression (MESR) method. This method of analysis is applied in this study instead of the PSM and other approaches available for impact evaluation. Following Dubin and McFadden (1984), Bourguignon, Fournier, and Gurgand (2007), this model yields consistent and efficient estimates. Bourguignon et al. (2007) point out that the MESR model provides a reasonable correction for the outcome equations, even when the IIA assumption is not achieved compared to other multinomial models especially when estimating outcomes over selected populations. This model is also advantageous in evaluating individual practices as well as combination of practices. At the same time, it is able to reveal the interactions between alternative practice options $(\mathrm{Wu}$ and Babcock, 1998).

The relationship between the outcome variables; maize yield (Mt/ha), inorganic fertilizer rate (Lit/ha), labour (Man-days/ha), and profit (Ghф) and the independent variables were specified, while the control group, non-adoption (conventional practices users) $\left(M_{o} R_{o} F_{o}\right)$ was the base outcome and denoted as $j=1$. Each outcome (maize yield, inorganic fertilizer rate, labour, and net profit) equation for each practice or combination of practices is specified as follows:

$$
\left\{\begin{array}{cc}
M_{0} R_{0} F_{0}: & Q_{1 i}=Z_{1 i} \gamma_{1}+u_{1 i} \\
\vdots & \vdots \\
M_{1} R_{1} F_{1}: & Q_{j i}=Z_{j i} \gamma_{j}+u_{j i}
\end{array} \quad, \quad j=2, \ldots, 8\right.
$$


Where $Q$ denotes the outcome variables - maize yield, inorganic fertilizer rate, labour, and profit respectively of the $i$ th farmer, $Z$ is a set of explanatory variables that influence (1) the outcome variables (maize output, farm size, seed rate, rate of organic manure application) and (2) the treatment group (gender, age, educ, MOcc, and Off-farm job). The error terms, denoted by $u$ 's, consist of unobservable individual effects $e_{\mathrm{i}}$ and a random error term $\varepsilon_{\mathrm{i}}$. If the $\varepsilon$ 's and $u$ 's are not independent, the OLS estimates in equation (1) will be biased. A consistent estimation of $\gamma_{j}$ requires the inclusion of the selection correction terms in equation (1) (Bourguignon et al., 2007). In the multinomial choice setting, there are $8-1$ selection correction terms, one for each practice. The MESR in equation (1) is re-specified as:

$$
\left\{\begin{array}{ccc}
M_{0} R_{0} F_{0}: & Q_{1 i}=Z_{1 i} \gamma_{1}+\sigma_{1} \hat{\lambda}_{1 i}+u_{1 i} & \text { if } I=1 \\
\vdots & \vdots & \\
M_{1} R_{1} F_{1}: & Q_{j i}=Z_{j i} \gamma_{j}+\sigma_{j} \hat{\lambda}_{j i}+u_{j i} & \text { if } I=j
\end{array} \quad j=2, \ldots, 8\right.
$$

Where $\sigma_{j}$ is the parameter of coefficients for $\hat{\lambda}_{j i}$, which shows the covariance between the $\varepsilon$ 's and $u$ 's. The framework developed above was used to examine the average treatment effect (ATE) by comparing the expected outcomes of adopters with that of non-adopters.

\subsection{Average Treatment Effect (ATE) Estimation}

In assessing the impact of the conservation practices on the outcome variables (maize yield, inorganic fertilizer rate, labour, and maize profit), counterfactuals which are the maize yield, inorganic fertilizer rate, labour, and maize profit that would have been obtained if the returns (coefficients) on the characteristics of adopters had been the same as the returns (coefficients) on the characteristics of the non-adopters, and vice versa were specified. This approach deals with both selection bias due to unobserved heterogeneity and controls for selection bias due to observed heterogeneity. Following Di Falco, Veronesi, and Yesuf (2011) the conditional expectation for the outcome variables were expressed and calculated from equation (2) as follows:

Adopters of conservation practices with adoption (actual):

$$
E\left[Q_{j i} \mid I=J, Z_{j i}, \hat{\lambda}_{j i}\right]=Z_{j i} \gamma_{j}+\hat{\lambda}_{j i} \theta_{j \varepsilon}
$$

Non-adopters (users of conventional practices) without adoption (actual):

Adopters had they decided not to adopt (counterfactual):

$$
E\left[Q_{1 i} \mid I=1, Z_{1 i}, \hat{\lambda}_{1 i}\right]=Z_{1 i} \gamma_{1}+\hat{\lambda}_{1 i} \theta_{1 \varepsilon}
$$

$$
E\left[Q_{1 i} \mid I=j, Z_{j i}, \hat{\lambda}_{j i}\right]=Z_{j i} \gamma_{1}+\hat{\lambda}_{j i} \theta_{1 \varepsilon}
$$

Non-adopters had they decided to adopt (counterfactual):

$$
E\left[Q_{j i} \mid I=1, Z_{1 i}, \hat{\lambda}_{1 i}\right]=Z_{1 i} \gamma_{j}+\hat{\lambda}_{1 i} \theta_{j \varepsilon}
$$

Equations (3) and (4) denotes the actual observed expected maize yield, inorganic fertilizer application rate, labour, and net profit in the sample for adopters and non-adopters respectively, and the counterfactual expected outcome for adopters and non-adopters were respectively represented by equations (5) and (6). These equations were used to calculate the average adoption effects (i.e. average impact on the outcome variables) on adopters which is given as the difference between equations (3) and (5) (Kassie et al., 2015) as follows:

$$
\begin{gathered}
A T E=E\left[Q_{j i} \mid I=j, Z_{j i}, \hat{\lambda}_{j i}\right]-E\left[Q_{1 i} \mid I=j, Z_{j i}, \hat{\lambda}_{j i}\right] \\
=Z_{j i}\left(\gamma_{j}-\gamma_{1}\right)+\hat{\lambda}_{j i}\left(\theta_{j}-\theta_{1}\right)
\end{gathered}
$$

The first term on the right-hand side of equation (7) represent the expected change in the outcome variables, if the characteristics and resources of adopters had the same returns (coefficients) as the returns on the characteristics and resources of non-adopters (Kassie, Teklewold, Marenya, Jaleta, \& Erenstein, 2015a). The first term on the right-hand side of equation (5) represents the expected change in adopters' mean outcome, if adopters' characteristics had the same return as non-adopters, i.e. if adopters had the same characteristics as non-adopters (Teklewold, Kassie, Shiferaw, \& Köhlin, 2013). The second term (i.e. $\lambda_{j}$ ) is the selection term that captures all potential effects of differences in unobserved variables. Similarly, the average effects of adoption of conservation practices on non-adopters had they adopted was computed as the difference between equations (4) 
and (6) as follows:

$$
E\left[Q_{1 i} \mid I=1, Z_{1 i}, \hat{\lambda}_{1 i}\right]=E\left[Q_{j i} \mid I=1, Z_{1 i}, \hat{\lambda}_{1 i}\right]=Z_{1 i}\left(\gamma_{j}-\gamma_{1}\right)+\hat{\lambda}_{j i}\left(\theta_{j}-\theta_{1}\right)
$$

According to Teklewold et al. (2013) and Kassie et al. (2015) average effects are insufficient for impact analysis due to its inability to account for both observed and unobserved factors influencing outcome variables, especially in cases of multiple adoption. The ATE which gives the difference of the expected outcomes between the treatment and control groups, is irrelevant to policy makers because it includes the effect on non-adopters (Heckman, 1997; Teklewold et al., 2013; Kassie et al., 2015). Heckman (1997) propose the Average Treatment Effect on Treated (ATET), which dwells solely on the effects on the treatment group. The Average Treatment Effect on Treated (ATET) is further estimated as the impact of adoption of conservation practices (true average adoption effect). The ATET compares the outcome variables of adopters with their counterfactuals (outcome variables had these same households not adopted these practices). The average treatment effects (ATEs) for maize yield, inorganic fertilizer rate, labour, and net profit were estimated using the augmented inverse-probability weights (AIPW), while the inverse-probability-weighted regression adjustment (IPWRA) method was used to estimate the average treatment effects on treated (ATETs) for maize yield, inorganic fertilizer rate, labour, and net profit. Both AIPW and IPWRA are "doubly robust" estimators, with the AIPW method including an augmentation term that corrects the estimator when the treatment model is mis-specified, unlike the regression adjustment (RA), and the inverse-probability weights (IPW) estimators (StataCorp., 2013).

\section{Results}

\subsection{Socio-Demographic and Farming Characteristics}

Of the sample, 49 are females representing 11.9 percent, and the remaining 362 males representing 88.1 percent (Table 2). Most of the respondents in the three districts are married (89.8\%), and have no formal education $(68.9 \%)$ with farming as the main occupation for most of the respondents $(82.7 \%)$. A minor of these farmers are civil servants, artisans, petty traders, and labourers.

Table 2. Socio-demographic and farming information

\begin{tabular}{|c|c|c|c|c|c|c|c|c|}
\hline & \multicolumn{2}{|c|}{ All farmers } & \multicolumn{2}{|c|}{ Kumbungu } & \multicolumn{2}{|c|}{ Yendi } & \multicolumn{2}{|c|}{ West Mamprusi } \\
\hline & Freq. & $(\%)$ & Freq. & $(\%)$ & Freq. & $(\%)$ & Freq. & $(\%)$ \\
\hline Total no. of respondents & 411 & 100 & 135 & 32.8 & 135 & 32.8 & 141 & 34.4 \\
\hline \multicolumn{9}{|l|}{ Gender: } \\
\hline $0=$ female & 49 & 11.9 & 1 & 0.7 & 4 & 3.0 & 44 & 31.2 \\
\hline $1=$ male & 362 & 88.1 & 134 & 99.3 & 131 & 97.0 & 97 & 68.8 \\
\hline \multicolumn{9}{|l|}{ Marital status: } \\
\hline $1=$ single & 38 & 9.2 & 5 & 3.7 & 12 & 8.9 & 21 & 14.9 \\
\hline $2=$ married & 369 & 89.8 & 129 & 95.6 & 123 & 91.1 & 117 & 83.0 \\
\hline $3=$ divorced & 4 & 1.0 & 1 & 0.7 & 0.0 & 0.0 & 3 & 2.1 \\
\hline $4=$ widowed & 0 & 0.0 & 0 & 0.0 & 0 & 0.0 & 0 & 0.0 \\
\hline
\end{tabular}

Level of formal education:

$\begin{array}{lllllllll}\text { None } & 283 & 68.9 & 96 & 71.1 & 91 & 67.4 & 96 & 68.1 \\ \text { Primary/middle } & 56 & 13.6 & 21 & 15.6 & 18 & 13.3 & 17 & 12.1 \\ \text { JHS } & 37 & 9.0 & 6 & 4.4 & 13 & 9.6 & 18 & 12.8 \\ \begin{array}{l}\text { Secondary } \\ \text { Tertiary }\end{array} & 28 & 6.8 & 10 & 7.4 & 11 & 8.1 & 7 & 5.0 \\ \text { main occupation: } & & 1.7 & 2 & 1.5 & 2 & 1.5 & 3 & 2.1 \\ \begin{array}{l}\text { 0 No } \\ \text { 1=Yes }\end{array} & 71 & 17.3 & 17 & 12.6 & 28 & 20.7 & 26 & 18.4 \\ \end{array}$




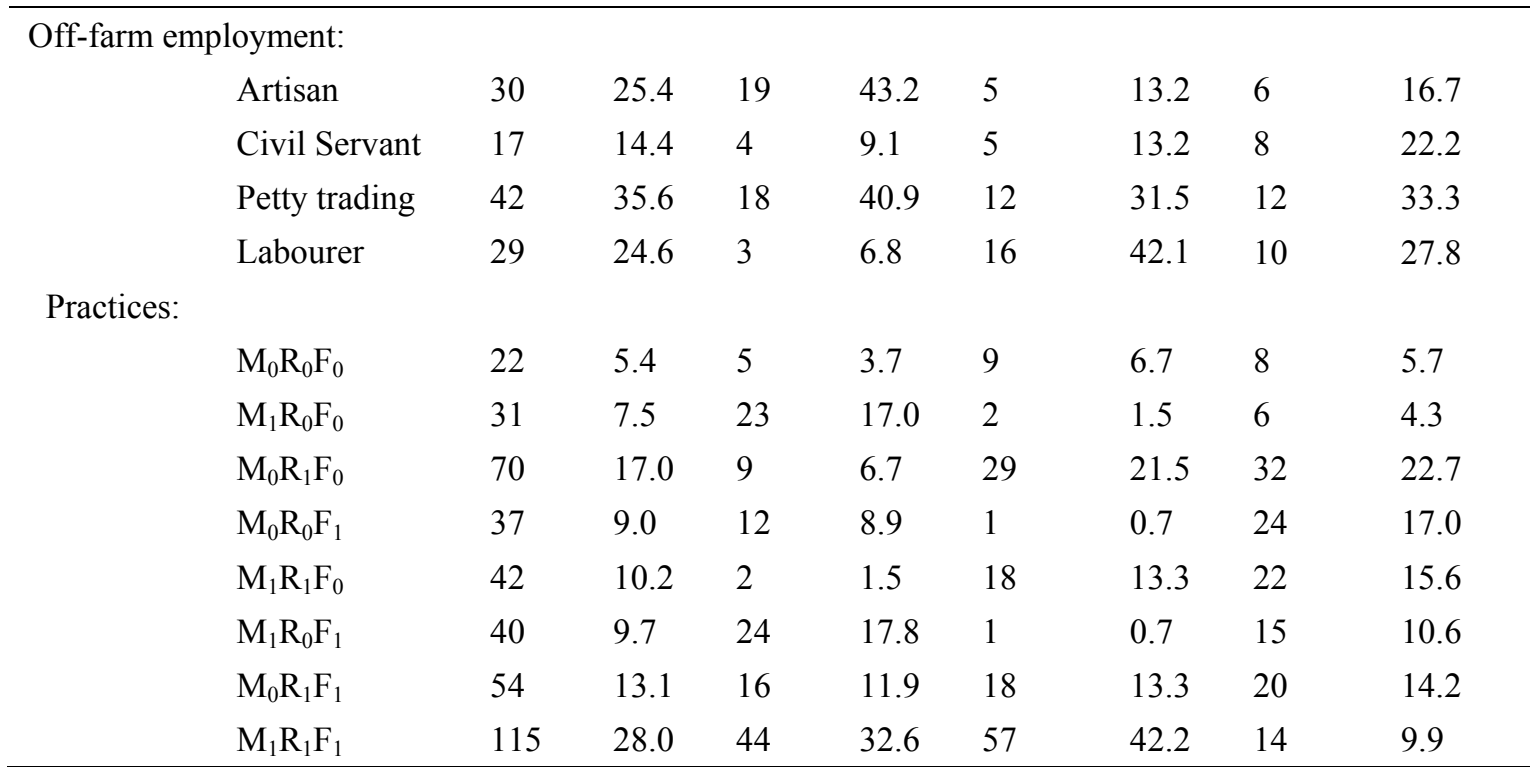

Source: Survey Data, July-August 2016

Note: adoption of conservation practices is denoted by $\mathrm{M}_{1}$ (minimum tillage), $\mathrm{R}_{1}$ (maize-legume rotation, and $\mathrm{F}_{1}$ (organic-inorganic fertilizer).

Of the sample, farmers using the three conservation practices $\left(\mathrm{M}_{1} \mathrm{R}_{1} \mathrm{~F}_{1}\right)$ form the majority $(28 \%)$. The minimum tillage practices in use by farmers in the three districts are planting on old ridges, use of bullocks for tilling, and the use of hand hoes for tillage (Table 3). Hand hoe use dominates the other practices with $52.4 \%$ of farmers against $23.8 \%$ each for the other practices. Cowpea, soybean, groundnut, and pigeon pea are the legumes used in rotation with maize, but soybean and groundnut use dominate with $44.64 \%$ and $44.3 \%$ of farmers respectively, because these legumes have relatively high demand on the market. Organic sources of fertilizer for the integrated fertilizer management practice are animal manure and compost, which are almost equally used by farmers.

Table 3 presents the specific conservation practices used by farmers in the three districts.

Table 3. Conservation practices in use

\begin{tabular}{lcc}
\hline Conservation practices & No. of farmers & $\begin{array}{l}\text { Proportion (\%) of farmers using } \\
\text { each conservation practice }\end{array}$ \\
\hline Minimum tillage & \\
1. Planting on old ridges & 20 & 23.8 \\
2. Use of bullock & 20 & 23.8 \\
3. Hand hoe & 44 & 52.4 \\
\hline Maize-legume rotation & & \\
1. Cowpea & 16 & 7.14 \\
2. Soy bean & 100 & 44.64 \\
3. Groundnut & 97 & 43.30 \\
4. Pigeon pea & 11 & 4.91 \\
\hline Organic-inorganic fertilizer & & \\
1. Manure & 57 & 48.72 \\
2. Compost & 60 & 51.28 \\
\hline
\end{tabular}

Source: Survey Data, July-August 2016

Most farmers (61.8\%) cultivate the local variety of maize, because of its ability to withstand both drought and 
diseases (Table 4). The hybrid varieties, though highly productive are less cultivated. Amongst the hybrid maize varieties cultivated, Obaatanpa is the most grown (22.9\%) (Table 4$)$. The variety least grown by farmers is yellow maize $(0.5 \%)$.

Table 4. Maize varieties cultivated by farmers

\begin{tabular}{ll}
\hline Maize variety & Proportion (\%) of farmers \\
\cline { 2 - 2 } Local & 61.8 \\
Okomasa & 10.9 \\
Obaatanpa & 22.9 \\
Popcorn & 0.5 \\
Dobidi & 2.2 \\
Laposta & 0.2 \\
Mamaba & 1.0 \\
Yellow maize & 0.5
\end{tabular}

Source: Survey Data, July-August 2016

The total number of adopters in the sample is 389 while that of non-adopters is 22 . Table 5 presents averages of some variables by status of adoption. The average age of adopters of conservation practices is 40.61 years, while that of non-adopters is 39.77 years. Formal education, proxied by the number of years spent in school is very low amongst both adopters and non-adopters with majority of them having no level of education. The average year in school for adopters is 0.59 with a deviation of 1.03 from the mean while that of non-adopters is 0.55 with a deviation of 0.80 . The average years of farming experience for non-adopters, 23.27years, is more than the mean years of experience of adopters (19.96). On average adopters seem to receive more frequent visits from agricultural extension agents with visits made 1.44 times per month compared to 1.05 times per month for non-adopters.

Table 5. Mean of variables by status of adoption

\begin{tabular}{lll}
\hline Variable & Adopters & Non-adopters \\
\hline Farm size in ha & 1.4082 & 1.1909 \\
& $(1.29716)$ & $(0.64874)$ \\
Age in years & 40.61 & 39.77 \\
& $(13.177)$ & $(16.251)$ \\
Years of experience in farming & 19.96 & 23.27 \\
Education in years & $(13.327)$ & $(14.871)$ \\
& 0.59 & 0.550 \\
Frequency of extension visits/2 months & $(1.030)$ & $(0.800)$ \\
& 1.44 & 1.05 \\
\hline
\end{tabular}

Source: Survey Data, July-August 2016. *Note: Standard deviations in parenthesis

\subsection{Impact of Conservation Practices on Maize Yield, Inorganic Fertilizer Rate, Labour, and Profits}

Result of the unconditional average effects of maize yield, inorganic fertilizer rate, labour, and maize profits presented in Table 6. 
Table 6. The average effect of adoption (ATE) of conservation practices

\begin{tabular}{|c|c|c|c|c|c|}
\hline \multirow{2}{*}{$\begin{array}{c}\text { Adoption effect } \\
\text { Conserv. } \\
\text { Practice(s) }\end{array}$} & & \multicolumn{4}{|c|}{ Outcome variables } \\
\hline & & $\begin{array}{l}\text { Maize yield } \\
(\mathrm{Mt} / \mathrm{ha})\end{array}$ & $\begin{array}{l}\text { Inorganic fertilizer rate } \\
\qquad(\mathrm{Kg} / \mathrm{ha})\end{array}$ & $\begin{array}{c}\text { Labour } \\
\text { (Man-days/ha) }\end{array}$ & $\begin{array}{c}\text { Maize profit } \\
\text { (Gh } \phi / \text { ha })\end{array}$ \\
\hline \multirow{7}{*}{$\begin{array}{l}\text { Average treatement effects } \\
\text { (ATE) }\end{array}$} & $\mathrm{M}_{1} \mathrm{R}_{0} \mathrm{~F}_{0}$ & $\begin{array}{c}0.558^{* *} \\
(0.258)\end{array}$ & $\begin{array}{c}0.265 \\
(0.864)\end{array}$ & $\begin{array}{c}31.75^{* * *} \\
(6.512)\end{array}$ & $\begin{array}{c}-773.7 * * * \\
(166.0)\end{array}$ \\
\hline & $\mathrm{M}_{0} \mathrm{R}_{1} \mathrm{~F}_{0}$ & $\begin{array}{l}0.468^{*} \\
(0.274)\end{array}$ & $\begin{array}{l}-0.185 \\
(0.779)\end{array}$ & $\begin{array}{l}12.10^{* *} \\
(4.709)\end{array}$ & $\begin{array}{c}-686.2^{* * *} \\
(184.4)\end{array}$ \\
\hline & $\mathrm{M}_{0} \mathrm{R}_{0} \mathrm{~F}_{1}$ & $\begin{array}{c}0.686^{* *} \\
(0.473)\end{array}$ & $\begin{array}{r}1.086 \\
(1.080)\end{array}$ & $\begin{array}{l}16.10^{*} \\
(8.302)\end{array}$ & $\begin{array}{l}-449.5 \\
(419.4)\end{array}$ \\
\hline & $\mathrm{M}_{1} \mathrm{R}_{1} \mathrm{~F}_{0}$ & $\begin{array}{c}0.364 \\
(0.277)\end{array}$ & $\begin{array}{l}0.385 \\
(0.734)\end{array}$ & $\begin{array}{l}10.95^{* *} \\
(5.278)\end{array}$ & $\begin{array}{c}-1,015 * * * \\
(166.6)\end{array}$ \\
\hline & $\mathrm{M}_{1} \mathrm{R}_{0} \mathrm{~F}_{1}$ & $\begin{array}{c}0.720^{* * *} \\
(0.275)\end{array}$ & $\begin{array}{c}0.486 \\
(0.889)\end{array}$ & $\begin{array}{l}12.16^{*} \\
(6.337)\end{array}$ & $\begin{array}{c}-675.1 * * * \\
(196.5)\end{array}$ \\
\hline & $\mathrm{M}_{0} \mathrm{R}_{1} \mathrm{~F}_{1}$ & $\begin{array}{c}0.658^{* *} \\
(0.300)\end{array}$ & $\begin{array}{c}0.713 \\
(0.697)\end{array}$ & $\begin{array}{l}9.534 * * \\
(4.520)\end{array}$ & $\begin{array}{c}-669.0^{* * *} \\
(167.9)\end{array}$ \\
\hline & $\mathrm{M}_{1} \mathrm{R}_{1} \mathrm{~F}_{1}$ & $\begin{array}{c}0.365 \\
(0.249)\end{array}$ & $\begin{array}{c}1.015 \\
(0.961)\end{array}$ & $\begin{array}{l}11.14 * * \\
(4.362)\end{array}$ & $\begin{array}{c}-909.4 * * * \\
(173.7)\end{array}$ \\
\hline
\end{tabular}

Source: Survey Data, July-August 2016. Robust standard errors in parentheses; $* * *$ indicates statistical significance at $1 \%, * *$ at $5 \%$, and at $* 10 \%$ levels.

The Average Treatment Effects (ATE) indicate that maize yields of adopters are higher than yields of non adopters in exception of adopters of both minimum tillage and maize-legume rotation practices $\left(\mathrm{M}_{1} \mathrm{R}_{1} \mathrm{~F}_{0}\right)$ and the joint adoption of all three practices $\left(\mathrm{M}_{1} \mathrm{R}_{1} \mathrm{~F}_{1}\right)$. Higher yields of adopters compared to yields of non-adopters imply that conservation practices contribute significantly to yields. This finding agrees with results of Thierfelder and Wall (2010), Rusinamhodzi et al. (2012), Ngwira et al. (2012), and Kassie et al. (2015) but contrasts findings of Rasul \& Thapa (2003).

The average difference in the rates of inorganic fertilizers is positive for all adopted practices except for adopters of maize-legume rotation practice $\left(\mathrm{M}_{0} \mathrm{R}_{1} \mathrm{~F}_{0}\right)$ who apply less fertilizers compared to non-adopters $\left(\mathrm{M}_{0} \mathrm{R}_{0} \mathrm{~F}_{0}\right)$ $(-0.185 \mathrm{Kg} / \mathrm{ha})$. The positive differences indicate that adopters are using more fertilizers per hectare compared to the rates applied by non-adopters (Table 6). However, these differences are not significant. The recommended rates of chemical fertilizers, according to scientists at the Soil-section of the CSIR-SARI, for the integrated organic-inorganic practice $\left(\mathrm{M}_{0} \mathrm{R}_{0} \mathrm{~F}_{1}\right)$ is approximately $70 \mathrm{~kg} / \mathrm{ha}$ and 1.5 tons of organic fertilizer (animal manure or compost) per hectare, and approximately $70 \mathrm{~kg}$ per hectare for the practice of maize-legume rotation (Appendix VI). The recommended rate for conventional farming, maize mono cropping $\left(\mathrm{M}_{0} \mathrm{R}_{0} \mathrm{~F}_{0}\right)$ is approximately $267 \mathrm{~kg} / \mathrm{ha}$. Despite these recommended rates, results of the study show that adopters are applying fertilizers more than the rates applied by non-adopters, which have negative implications for both the environment and health of consumers. According to Carter, Noronha, Peters, and Kimpinski (2009), Miriti et al. (2012), and Palm, Blanco-Canqui, DeClerck, Gatere, and Grace (2014) conservation agricultural practices improve soils organic carbon (C), soil particulate $\mathrm{C}$ and nitrogen $(\mathrm{N})$ which can contribute to reduce soils' fertilizer requirements. The applications of higher rates of chemical fertilizers also mean higher costs, which can translate to reduce profits for adopters.

Adopters of all the conservation practices use significantly more labour compared to non-adopters. The highest average difference in labour between adopters of minimum tillage practice $\left(\mathrm{M}_{1} \mathrm{R}_{0} \mathrm{~F}_{0}\right)$ and non-adopters $\left(\mathrm{M}_{0} \mathrm{R}_{0} \mathrm{~F}_{0}\right)$ is 31.75 Man-days/ha (Table 6). A minimum tillage practice, especially one that involves the use of hand hoes requires more labour for tillage operations, explaining the significant labour by adopters of this practice. Increase in on-farm employment is important for the social pillar of sustainability (Riesgo and Gómez-Limón 2006; Gómez-Limón and Sanchez-Fernandez 2010), however, this has negative implications for profits of adopters.

Average profits are lower for adopters of all the conservation practices compared to the average profit for 
non-adopters. This is indicated by the significant and negative average differences. Adopters of both minimum tillage and maize-legume rotation practices $\left(\mathrm{M}_{1} \mathrm{R}_{1} \mathrm{~F}_{0}\right)$ have the lowest profits compared to that of non-adopters with an average effect of $-1,015 \mathrm{Gh} \phi / \mathrm{ha}$. This result reiterates that observed by Corbeels et al. (2014) where adoption of CA did not increase farm profits compared to the profits of non-adopters. The lower incomes could be due to the fact that more inputs especially labour is required by adopters in implementing conservation practices, thus increasing the variable costs of operation.

Estimates of Average Treatment Effect (ATE) only show the difference of expected outcomes between adopters and non-adopters. The Average Treatment Effect on Treated (ATET) estimates the impact or true average adoption effect of households by comparing the outcome variables of adopters with the outcome variables had these same households not adopted these practices. Results of the average treatment effects on treated are presented in Table 7.

Table 7. The average treatment effect on treated (ATET) of adoption of conservation practices

\begin{tabular}{|c|c|c|c|c|c|}
\hline \multirow{2}{*}{\multicolumn{2}{|c|}{$\begin{array}{c}\text { Adoption effect } \\
\text { Conserv. } \\
\text { Practice(s) }\end{array}$}} & \multicolumn{4}{|c|}{ Outcome variables } \\
\hline & & $\begin{array}{c}\text { Maize yield } \\
\text { (Mt/ha) }\end{array}$ & $\begin{array}{c}\text { Inorganic } \\
\text { fertilizer rate } \\
(\mathrm{Kg} / \mathrm{ha})\end{array}$ & $\begin{array}{c}\text { Labour } \\
\text { (Man-days/ha) }\end{array}$ & $\begin{array}{c}\text { Maize profit } \\
(\mathrm{Gh} \phi / \mathrm{ha})\end{array}$ \\
\hline \multirow{14}{*}{$\begin{array}{c}\text { Average } \\
\text { treatment } \\
\text { effects on } \\
\text { treated } \\
\text { (ATET) }\end{array}$} & \multirow{2}{*}{$\mathrm{M}_{1} \mathrm{R}_{0} \mathrm{~F}_{0}$} & 0.259 & -503.8 & $32.55 * * *$ & $-1,604 * * *$ \\
\hline & & (1.016) & $(1,468)$ & $(8.195)$ & $(392.2)$ \\
\hline & \multirow{2}{*}{$\mathrm{M}_{0} \mathrm{R}_{1} \mathrm{~F}_{0}$} & 1.880 & -504.7 & $12.07 *$ & $-1,759 * * *$ \\
\hline & & $(1.728)$ & $(1,468)$ & $(7.042)$ & $(435.1)$ \\
\hline & \multirow{2}{*}{$\mathrm{M}_{0} \mathrm{R}_{0} \mathrm{~F}_{1}$} & 1.244 & -375.2 & $34.14 * * *$ & -962.3 \\
\hline & & (1.118) & $(1,454)$ & $(21.67)$ & $(642.7)$ \\
\hline & \multirow{2}{*}{$\mathrm{M}_{1} \mathrm{R}_{1} \mathrm{~F}_{0}$} & 0.202 & -452.1 & $13.82^{* *}$ & $-1,919 * * *$ \\
\hline & & $(1.027)$ & $(1,438)$ & $(6.948)$ & $(438.2)$ \\
\hline & \multirow{2}{*}{$\mathrm{M}_{1} \mathrm{R}_{0} \mathrm{~F}_{1}$} & 0.646 & -502.7 & $15.70^{* *}$ & $-1,625^{* * *}$ \\
\hline & & $(1.029)$ & $(1,468)$ & $(7.671)$ & $(444.2)$ \\
\hline & \multirow{2}{*}{$\mathrm{M}_{0} \mathrm{R}_{1} \mathrm{~F}_{1}$} & 0.773 & -467.7 & 11.26 & $-1,579 * * *$ \\
\hline & & $(1.136)$ & $(1,445)$ & $(6.849)$ & $(489.8)$ \\
\hline & \multirow{2}{*}{$\mathrm{M}_{1} \mathrm{R}_{1} \mathrm{~F}_{1}$} & 0.241 & -500.3 & $16.97^{* *}$ & $-1,660 * * *$ \\
\hline & & $(1.011)$ & $(1,468)$ & (6.638) & (471.1) \\
\hline
\end{tabular}

Source: Survey Data, July-August 2016. Robust standard errors in parentheses; *** indicates statistical significance at $1 \%,{ }^{* *}$ at $5 \%$, and at $* 10 \%$ levels.

The ATET results indicate an insignificant impact of adoption of conservation practices on both maize yields and inorganic fertilizer rates, contrary to findings such as that of Laik et al. (2014) and Rockstrom et al. (2009). This implies that no difference exists in both maize yields and fertilizer application rates of adopters compared to the yields and rates applied if these same farmers had not adopted these conservation practices.

The recommended rate of chemical fertilizer, NPK (15-15-15) according to scientists at the Council for Scientific and Industrial Research - Savanna Agricultural Research Institute (CSIR-SARI) are approximately; $270 \mathrm{~kg} / \mathrm{ha}$ for mono-cropping of maize, $135 \mathrm{~kg} / \mathrm{ha}$ for maize-legume rotations, $70 \mathrm{~kg} / \mathrm{ha}$ for integrated organic-inorganic fertilizer application, and $35 \mathrm{~kg} / \mathrm{ha}$ for adoption of both maize-legume rotation and integrated fertilizers.

Adoption impacts positively on labour, by increasing the average number of labour used per hectare of plot as indicated by the significant and positive ATET results in Table 7. Results imply that adopters would have required averagely less labour if they had not adopted conservation practices. Though the increase in labour demand per hectare increases with adoption of conservation practices, it has negative implications for the smallholder farmer by increasing the variable cost incurred in the production of maize leading to a decline in 
profits. Similar results were obtained for adopters of conservation practices in the study of Teklewold et al. (2013).

Adoption impacts negatively on profits, indicated by the significant and negative ATET results for all the adopted practices. The results show that profits would have been far lower had adopters of all the conservation practices not adopted these practices. Teklewold et al. (2013) on the contrary observe that adoption of conservation practices impacts significantly and positively on profits. The lower profits obtained could be linked to higher variable costs of operation especially from the rise in labour demand. This result has critical implications for attaining economic sustainability in production.

\section{Conclusion and Policy Recommendation}

Applying the MESR model in this study and using a cross-sectional data, this study analysed the impact of adoption of minimum tillage, maize-legume rotation, and integrated organic-inorganic fertilizer practices on both inputs use and performance (yield and profits). Results of the study reveal that conservation practices have a positive impact on farm employment, but impacts negatively on profits of adopters, which is detrimental economically to these smallholder commercial maize producers. Adoption of these practices had no impact on maize yields and on inorganic fertilizer rates.

Both international and local organisations facilitating the adoption of conservation agricultural practices must intensify training on strategies that minimize costs of production and which leads to raise profits of adopters. Technical assistance on required application rates of fertilizers for each practice or combination of practices should be offered to reduce significantly the rates of fertilizers applied by adopters.

\section{References}

Abdulai, A., \& Huffman, W. (2014). The Adoption and Impact of Soil and Water Conservation Technology: An Endogenous Switching Regression Application. Land Economics, 90(1), 26-43. https://doi.org/10.3368/le.90.1.26

Akowuah, P. (2010). Farmers Experience and Practice of No-tillage System: Towards the Adoption of Conservation Agricultural Production in Atwima-Nwabiagya District of Ashanti Region, Ghana. Journal of Developments in Sustainable Agriculture, 5, 191-202.

Angelucci, F. (2013). Analysis of incentives and disincentives for maize in Ghana. Technical notes series, MAFAP, FAO, Rome.

Arslan, A., McCarthy, N., Lipper, L., Asfaw, S., \& Cattaneo, A. (2014). Adoption and intensity of adoption of conservation farming practices in Zambia. Agriculture, Ecosystems and Environment, 187, 72-86. https://doi.org/10.3368/le.90.1.26

Bartlett, J. E., Kotrlik, J. W. K. J. W., \& Higgins, C. (2001). Organizational research: determining appropriate sample size in survey research appropriate sample size in survey research. Information Technology, Learning, and Performance Journal, 19(1), 43-50.

Basu, P., \& Scholten, B. a. (2012). Technological and social dimensions of the Green Revolution: connecting pasts and futures. International Journal of Agricultural Sustainability, 10(2), 109-116. https://doi.org/10.1080/14735903.2012.674674

Birner, R., \& Resnick, D. (2010). The Political Economy of Policies for Smallholder Agriculture. World Development, 38(10), 1442-1452. https://doi.org/10.1016/j.worlddev.2010.06.001

Boahen, P., Dartey, B. A., Dogbe, G. D., Boadi, E. A., Triomphe, B., Daamgard-Larsen, S., Ashburner, J. (2007). Conservation Agriculture as Practised in Ghana. Nairobi. African Conservation Tillage Network, Centre de Coopération Internationale de Recherche Agronomique Pour Le Développement, Food and Agriculture Organization of the United Nations., 1-71.

Bolliger, A., Magid, J., Amado, J. C. T., Skóra Neto, F., Ribeiro, M. D. F. D. S., Calegari, A., ... de Neergaard, A. (2006). Taking Stock of the Brazilian “Zero-Till Revolution": A Review of Landmark Research and Farmers' Practice. Advances in Agronomy, 91(6), 47-110. https://doi.org/10.1016/S0065-2113(06)91002-5

Bourguignon, F., Fournier, M., \& Gurgand, M. (2007). Selection bias corrections based on the multinomial logit model: Monte Carlo comparisons. Journal of Economic Surveys, 21(1), 174-205. https://doi.org/10.1111/j.1467-6419.2007.00503.x 
Brouder, S. M., \& Gomez-Macpherson, H. (2014). The impact of conservation agriculture on smallholder agricultural yields: A scoping review of the evidence. Agriculture, Ecosystems and Environment, 187, 11-12. https://doi.org/10.1016/j.agee.2013.08.010

Carter, M. R., Noronha, C., Peters, R. D., \& Kimpinski, J. (2009). Influence of conservation tillage and crop rotation on the resilience of an intensive long-term potato cropping system: Restoration of soil biological properties after the potato phase. Agriculture, Ecosystems and Environment, 133, 32-39. https://doi.org/10.1016/j.agee.2009.04.017

Corbeels, M., de Graaff, J., Ndah, T. H., Penot, E., Baudron, F., Naudin, K., ... Adolwa, I. S. (2014). Understanding the impact and adoption of conservation agriculture in Africa: A multi-scale analysis. Agriculture, Ecosystems and Environment, 187, 155-170. https://doi.org/10.1016/j.agee.2013.10.011

Dalton, T. J., Yahaya, I., \& Naab, J. (2014). Perceptions and performance of conservation agriculture practices in northwestern Ghana. Agriculture, Ecosystems and Environment, 187, 65-71. https://doi.org/10.1016/j.agee.2013.11.015

Di Falco, S., Veronesi, M., \& Yesuf, M. (2011). Does adaptation to climate change provide food security? A micro-perspective from Ethiopia. American Journal of Agricultural Economics, 93(January), 825-842. https://doi.org/10.1093/ajae/aar006

Dubin, J.A., McFadden, D. L. (1984). An Econometric Analysis of Residential Electric Appliance Holdings and Consumption. Econometrica, 52(2), 345-362. https://doi.org/10.2307/1911493

Efthimiadou, A., Bilalis, D., Karkanis, A., \& Froud-Williams, B. (2010). Combined organic/inorganic fertilization enhance soil quality and increased yield, photosynthesis and sustainability of sweet maize crop. Australian Journal of Crop Science, 4(9), 722-729.

Erenstein, O. (2003). Smallholder conservation farming in the tropics and sub-tropics: A guide to the development and dissemination of mulching with crop residues and cover crops. Agriculture, Ecosystems and Environment, 100, 17-37. https://doi.org/10.1016/S0167-8809(03)00150-6

Etwire, P.M., Al-Hassan, R. M., Kuwornu, J. K. M., Osei-Owusu, Y. (2013). Smallholder farmers' adoption of technologies for adaptation to climate change in Northern Ghana. Journal of Agricultural Extension and Rural Development, 5(6), 121-129.

Giller, K. E., Witter, E., Corbeels, M., \& Tittonell, P. (2009). Conservation agriculture and smallholder farming in Africa: The heretics' view. Field Crops Research, 114, 23-34. https://doi.org/10.1016/j.fcr.2009.06.017

Gómez-Limón, J. a., \& Sanchez-Fernandez, G. (2010). Empirical Evaluation of Agricultural Sustainability using $\begin{array}{llll}\text { Composite Indicators. Ecological } & \text { Economics, }\end{array}$ https://doi.org/10.1016/j.ecolecon.2009.11.027

Gowing, J. W., \& Palmer, M. (2008). Sustainable agricultural development in sub-Saharan Africa: the case for a paradigm shift in land husbandry. Soil Use and Management, 24, 92-99. https://doi.org/10.1111/j.1475-2743.2007.00137.x

Heckman, J. (1997). Instrumental Variables : A Study of Implicit Behavioral Assumptions Used in Making Program Evaluations. The Journal of Human Resources, 32(3), 441-462. https://doi.org/10.2307/146178

Hobbs, P. R., Sayre, K., \& Gupta, R. (2008). The role of conservation agriculture in sustainable agriculture. Philosophical Transactions of the Royal Society of London B: Biological Sciences, 363, 543-555. https://doi.org/10.1098/rstb.2007.2169

Kassam, A., Friedrich, T., Shaxson, F., \& Pretty, J. (2009). The spread of Conservation Agriculture: justification, sustainability and uptake. International Journal of Agricultural Sustainability, 7(4), 292-320. https://doi.org/10.3763/ijas.2009.0477

Kassie, M., Teklewold, H., Marenya, P., Jaleta, M., \& Erenstein, O. (2015). Production Risks and Food Security under Alternative Technology Choices in Malawi: Application of a Multinomial Endogenous Switching Regression. Journal of Agricultural Economics, 66(3), 640-659. https://doi.org/10.1111/1477-9552.12099

Laik, R., Sharma, S., Idris, M., Singh, a. K., Singh, S. S., Bhatt, B. P., ... Ladha, J. K. (2014). Integration of conservation agriculture with best management practices for improving system performance of the rice-wheat rotation in the Eastern Indo-Gangetic Plains of India. Agriculture, Ecosystems and Environment, 195, 68-82. https://doi.org/10.1016/j.agee.2014.06.001 
Martey, E., Wiredu, A. N., Etwire, P. M., Buah, S. S. J., Fosu, M., Bidzakin, J., ... Kusi, F. (2014). Fertilizer Adoption and Use Intensity Among Smallholder Farmers in Northern Ghana: A Case Study of the AGRA Soil Health Project. Sustainable Agriculture Research, 3(1), 24-36. https://doi.org/10.5539/sar.v3n1p24

Miriti, J. M., Kironchi, G., Esilaba, a. O., Heng, L. K., Gachene, C. K. K., \& Mwangi, D. M. (2012). Yield and water use efficiencies of maize and cowpea as affected by tillage and cropping systems in semi-arid Eastern Kenya. Agricultural Water Management, 115, 148-155. https://doi.org/10.1016/j.agwat.2012.09.002

Ngwira, A. R., Aune, J. B., \& Mkwinda, S. (2012). On-farm evaluation of yield and economic benefit of short term maize legume intercropping systems under conservation agriculture in Malawi. Field Crops Research, 132, 149-157. https://doi.org/10.1016/j.fcr.2011.12.014

Palm, C., Blanco-Canqui, H., DeClerck, F., Gatere, L., \& Grace, P. (2014). Conservation agriculture and ecosystem services: An overview. Agriculture, Ecosystems and Environment, 187, 87-105. https://doi.org/10.1016/j.agee.2013.10.010

Pannell, D. J., Llewellyn, R. S., \& Corbeels, M. (2014). The farm-level economics of conservation agriculture for resource-poor farmers. Agriculture, Ecosystems and Environment, 187, 52-64. https://doi.org/10.1016/j.agee.2013.10.014

Pedzisa, T., Rugube, L., Winter-Nelson, A., Baylis, K., \& Mazvimavi, K. (2015). Abandonment of Conservation Agriculture by Smallholder Farmers in Zimbabwe. Agrekon, 54(3), 1-22. https://doi.org/10.1080/03031853.2015.1084939

Rasul, G., \& Thapa, G. B. (2003). Sustainability analysis of ecological and conventional agricultural systems in Bangladesh. World Development, 31(10), 1721-1741. https://doi.org/10.1016/S0305-750X(03)00137-2

Riesgo, L., \& Gómez-Limón, J. a. (2006). Multi-criteria policy scenario analysis for public regulation of irrigated agriculture. Agricultural Systems, 91, 1-28. https://doi.org/10.1016/j.agsy.2006.01.005

Rockstrom, J., Kaumbutho, P., Mwalley, J., Nzabi, a. W., Temesgen, M., Mawenya, L., ... Damgaard-Larsen, S. (2009). Conservation farming strategies in East and Southern Africa: Yields and rain water productivity from on-farm action research. Soil and Tillage Research, 103, 23-32. https://doi.org/10.1016/j.still.2008.09.013

Rusinamhodzi, L., Corbeels, M., Nyamangara, J., \& Giller, K. E. (2012). Maize-grain legume intercropping is an attractive option for ecological intensification that reduces climatic risk for smallholder farmers in central Mozambique. Field Crops Research, 136, 12-22. https://doi.org/10.1016/j.fcr.2012.07.014

Sarpong, D. B., \& Anyidoho, N. A. (2012). Climate Change and Agricultural Policy Processes in Ghana. Future Agricultures, working paper, 45 (pp. 1-20).

Silici, L., Ndabe, P., Friedrich, T., \& Kassam, A. (2011). Harnessing sustainability, resilience and productivity through conservation agriculture: the case of likoti in Lesotho. International Journal of Agricultural Sustainability, 9(1), 137-144. https://doi.org/10.3763/ijas.2010.0555

Sommer, R., Thierfelder, C., Tittonell, P., Hove, L., Mureithi, J., \& Mkomwa, S. (2014). Fertilizer use should not be a fourth principle to define conservation agriculture. Response to the opinion paper of Vanlauwe et al. (2014) 'A fourth principle is required to define conservation agriculture in sub-Saharan Africa: The appropriate use of fe. Field Crops Research, 169, 145-148. https://doi.org/10.1016/j.fcr.2014.05.012

StataCorp. (2013). Stata: Release 13. Statistical Software. College Station, TX: StataCorp LP.

Stonehouse, D. P. (1997). Socio-economics of alternative tillage systems. Soil and Tillage Research, 43, 109-130. https://doi.org/10.1016/S0167-1987(97)00037-8

Teklewold, H., Kassie, M., Shiferaw, B., \& Köhlin, G. (2013). Cropping system diversification, conservation tillage and modern seed adoption in Ethiopia: Impacts on household income, agrochemical use and demand for labor. Ecological Economics, 93, 85-93. https://doi.org/10.1016/j.ecolecon.2013.05.002

Thierfelder, C., \& Wall, P. C. (2010). Rotation in Conservation Agriculture Systems of Zambia: Effects on Soil Quality and Water Relations. Experimental Agriculture, 46(3), 309-325. https://doi.org/10.1017/S001447971000030X

Vanlauwe, B., Coyne, D., Gockowski, J., Hauser, S., Huising, J., Masso, C., ... Van Asten, P. (2014). Sustainable intensification and the African smallholder farmer. Current Opinion in Environmental Sustainability, 8, 15 22. https://doi.org/10.1016/j.cosust.2014.06.001 
Vanlauwe, B., Wendt, J., Giller, K. E., Corbeels, M., Gerard, B., \& Nolte, C. (2014). A fourth principle is required to define Conservation Agriculture in sub-Saharan Africa: The appropriate use of fertilizer to enhance crop productivity. Field Crops Research, 155, 10-13. https://doi.org/10.1016/j.fcr.2013.10.002

Wall, C. P. (2007). Managing Soils for Food Security and Climate Change. Journal of Crop Improvement, 19(1-2), 137-155. https://doi.org/10.1300/J411v19n01_07

Wall, P. C., Thierfelder, C., Ngwira, A., Govaerts, B., Nyagumbo, I., Baudron, F., ... Kassam, a H. (2013). Conservation agriculture in Eastern and Southern Africa. In R. A. Jat, \& J. Graziano de Silva (Eds.), Conservation Agriculture: Global Prospects and Challenges (pp. 263-292). CABI, Cambridge USA.

Webster, J. P. G. (1997). Assessing the Economic Consequences of Sustainability in Agriculture. Agriculture, Ecosystems \& Environment, 64, 95-102. https://doi.org/10.1016/S0167-8809(97)00027-3

Wu, J., \& Babcock, B. A. (1998). The Choice of Tillage, Rotation, and Soil Testing Practices: Economic and Environmental Implications. American Journal of Agricultural Economics, 80, 494-511. https://doi.org/10.2307/1244552

\section{Notes}

Note 1. Though the goals of both organic farming and CA are to reduce pollution and promote natural soil processes, the two concepts are not the same (Gowing and Palmer, 2008). Conservation Agriculture (CA) allows the use of agrochemicals (e.g. fertilizers, weedicides), while organic farming prohibits their use.

Note 2. "Full adoption of CA" is realized when individual practices are combined in a unified, locally adapted manner, with the simultaneous application of the three principles (Erenstein, 2003). On the other hand, the use of practices that embody either one or two of the three CA principles is referred to as "partial CA.

\section{Copyrights}

Copyright for this article is retained by the author(s), with first publication rights granted to the journal.

This is an open-access article distributed under the terms and conditions of the Creative Commons Attribution license (http://creativecommons.org/licenses/by/4.0/). 